\title{
Association of electrostimulation with cell transplantation in ischemic heart disease
}

\author{
Abdel Shafy, MD, ${ }^{\mathrm{a}}$ Thomas Lavergne, $\mathrm{MD},{ }^{\mathrm{b}}$ Christian Latremouille, $\mathrm{MD}, \mathrm{PhD},{ }^{\mathrm{a}}$ \\ Miguel Cortes-Morichetti, MD, ${ }^{\mathrm{b}}$ Alain Carpentier, $\mathrm{MD}, \mathrm{PhD},{ }^{\mathrm{a}}$ and Juan C. Chachques, MD, PhD ${ }^{\mathrm{a}}$
}

\begin{abstract}
Background: Until now, cell therapy has constituted a passive therapeutic approach; the only effects seem to be related to the reduction of the myocardial fibrosis and the limitation of the adverse ventricular remodeling. Cardiac resynchronization therapy is indicated in patients with heart failure to correct conduction disorders associated with chronic systolic and diastolic dysfunction. The association of electrostimulation with cellular cardiomyoplasty could be a way to transform passive cell therapy into "dynamic cellular support." Electrostimulation of ventricles following skeletal myoblast implantation should induce the contraction of the transplanted cells and a higher expression of slow myosin, which is better adapted for chronic ventricular assistance. The purpose of this study is to evaluate myogenic cell transplantation in an ischemic heart model associated with cardiac resynchronization therapy.
\end{abstract}

Methods: Twenty two sheep were included. All animals underwent myocardial infarction by ligation of 2 coronary artery branches (distal left anterior descending artery and D2). After 4 weeks, autologous cultured myoblasts were injected in the infarcted areas with or without pacemaker implantation. Atrial synchronized biventricular pacing was performed using epicardial electrodes. Echocardiography was performed at 4 weeks (baseline) and 12 weeks after infarction.

Results: Echocardiography showed a significant improvement in ejection fraction and limitation of left ventricular dilatation in cell therapy with cardiac resynchronization therapy as compared with the other groups. Viable cells were identified in the infarcted areas. Differentiation of myoblasts into myotubes and enhanced expression of slow myosin heavy chain was observed in the electrostimulated group. Transplantation of cells with cardiac resynchronization therapy caused an increase in diastolic wall thickening in the infarcted zone relative to cells-only group and cardiac resynchronization therapy-only group.

Conclusions: Biventricular pacing seems to induce synchronous contraction of transplanted myoblasts and the host myocardium, thus improving ventricular function. Electrostimulation was related with enhanced expression of slow myosin and the organization of myoblasts in myotubes, which are better adapted at performing cardiac work. Patients with heart failure presenting myocardial infarct scars and indication for cardiac resynchronization therapy might benefit from simultaneous cardiac pacing and cell therapy.

Cell transplantation for cardiac support and regeneration may repair the injured heart but is limited by poor effect in systolic function. This can be due to the lack of gap junctions between the native myocardium and the grafted cells. Also, cell transplantation seems to be limited by death of transplanted cells. ${ }^{1-4}$ Most cell death occurs in the first few days posttransplantation, likely from a combination of ischemia, anoikis, and inflammation. Anoikis is a form of apoptosis that is induced by anchorage-dependent cells detaching from the surrounding extracellular matrix. Interventions known to enhance transplanted cell survival

From the Laboratory of Biosurgical Research ${ }^{\mathrm{a}}$ and Department of Cardiology, ${ }^{\mathrm{b}}$ Pompidou Hospital, University of Paris, Paris, France.

Received for publication July 30, 2008; revisions received Jan 2, 2009; accepted for publication Feb 3, 2009; available ahead of print April 10, 2009.

Address for reprints: Juan C. Chachques, MD, PhD, Department of Cardiovascular Surgery, Pompidou Hospital, 20 rue Leblanc, 75015 Paris, France (E-mail: j.chachques@ brs.aphp.fr).

J Thorac Cardiovasc Surg 2009;138:994-1001

$0022-5223 / \$ 36.00$

Copyright (c) 2009 by The American Association for Thoracic Surgery

doi:10.1016/j.jtcvs.2009.02.025 include heat shock, overexpressing antiapoptotic proteins, free radical scavengers, anti-inflammatory therapy, and codelivery of extracellular matrix molecules. Combinatorial use of such interventions could enhance graft cell survival. ${ }^{5}$ Despite these possibilities, until now cell transplantation has constituted a passive therapeutic approach; the only effects seem to be related to the reduction of the myocardial fibrosis and the limitation of the adverse ventricular remodeling. ${ }^{6,7}$

Atrial synchronized biventricular pacing for cardiac resynchronization therapy (CRT) is indicated in patients with heart failure to correct conduction disorders associated with chronic systolic and diastolic dysfunction. ${ }^{8-10}$ The association of electrostimulation with cellular cardiomyoplasty could be a way to transform passive cell therapy into "dynamic cellular support." The principles of electrophysiologic conditioning of skeletal muscle fibers (eg, as developed for dynamic cardiomyoplasty procedure) can be applied in cellular cardiomyoplasty. ${ }^{11}$ The hypothesis is that electrostimulation of both ventricles following skeletal 


\section{Abbreviations and Acronyms}

CRT = cardiac resynchronization therapy

DAPI $=4^{\prime}, 6$-diamidino-2-phenylindole

$\mathrm{LV} \quad=$ left ventricular

LVEDV $=$ left ventricular end-diastolic volume

myoblast implantation should induce the contraction of the transplanted cells and a higher expression of slow myosin, which is better adapted for chronic ventricular assistance. The purpose of this study is to evaluate myogenic cell transplantation in an ischemic heart model ${ }^{12,13}$ associated with atrial synchronized biventricular pacing.

\section{MATERIALS AND METHODS}

\section{Experimental Animals}

In 22 female Rambouillet sheep weighing 21 to $34 \mathrm{~kg}$ (mean, $30 \pm 3.5$ $\mathrm{kg}$ ), a left ventricular (LV) myocardial infarct was surgically created by ligation of 2 coronary artery branches (distal left anterior descending artery and D2). During the procedure, a skeletal muscle biopsy was performed.

Four weeks after coronary artery ligation, 4 different treatment groups were defined: group 1 (control, $\mathrm{n}=5$ ): surgical injection of cell culture medium in the infarcted area; group 2 (cell therapy, $\mathrm{n}=5$ ): intrainfarct implantation of autologous myoblasts (70 million cells); group $3(\mathrm{CRT}, \mathrm{n}=5)$ : biventricular cardiac pacing alone; group 4 (cells + CRT, $n=5$ ): intrainfarct implantation of myoblasts associated with cardiac pacing.

In the CRT group, atrial synchronized biventricular pacing using epicardial electrodes was performed after cell implantation (study design in Figure 1).

All animals were treated according to the guidelines of the French National Institute of Health and Medical Research (INSERM).

\section{Anesthetic Management}

Premedication was carried out by intramuscular injection of acepromazine (Vetranquil; Sanofi, Paris, France) $150 \mathrm{mg}$. The animals were prepared for surgery, using a jugular venous line and an auricular arterial line. For anesthesia, propofol (Diprivan; AstraZeneca, Rueil-Malmaison, France) was administered though the venous line at a concentration of $6 \mathrm{mg} / \mathrm{kg}$. Ventilation was ensured though an endotracheal probe (No. 7) connected to a Siemens 900C respirator (Siemens AG, Munich, Germany) using the following parameters: volume of $10 \mathrm{~mL} / \mathrm{kg}$, frequency of 24 breaths/min, and inspired oxygen fraction of $60 \%$. Anesthesia was maintained by inhalation of isoflurane $1 \%$ to $2 \%$. Postoperative management of the sheep consisted of cefazolin injected intramuscularly at $1 \mathrm{~g}$ per day during 5 days.

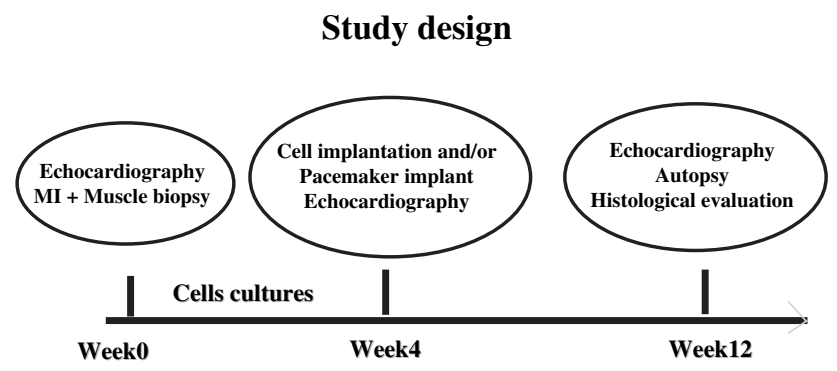

FIGURE 1. Study design. $M I$, Myocardial infarction.

\section{Skeletal Muscle Explantation and Myocardial Infarction}

A $2-\mathrm{cm}^{3}$ skeletal muscle fragment was taken from the left posterior femoral biceps of each sheep under sterile conditions. The biopsy tissue was kept in Hanks balanced salt solution (Life Technologies, Rockville, Md) at $4{ }^{\circ} \mathrm{C}$ until the cell culture was started.

Via a left thoracotomy, the ligation of the distal homonymous (equivalent to human left anterior descending) and second diagonal coronary arteries produced a constant transmural myocardial infarction (Figure 2). To reduce the risk of ventricular fibrillation, lidocaine $1 \%\left(2 \mathrm{mg} \cdot \mathrm{kg}^{-1}\right.$ - $\mathrm{h}^{-1}$ ) was administered intravenously during the entire surgical procedure. Thereafter, the thoracic wall was closed after placing a chest tube in the pleural cavity. The drain was removed as soon as the sheep started spontaneous respiration. The severity of the myocardial injury was evaluated by cardiac troponin I serum levels measured 24 hours after infarction.

\section{Satellite Cell Isolation and Culture}

Skeletal myoblasts obtained from autologous muscle biopsy samples were isolated, purified, and cultured as previously described. ${ }^{7}$ In brief, the cells were cultured for 4 weeks in Ham's F12 medium containing 20\% fetal calf serum and $1 \%$ penicillin/streptomycin. To reduce the number of fibroblasts and achieve a pure myoblast culture, a preplating step was applied on the first passage. The preplating technique was based on the quicker attachment of fibroblasts compared with satellite cells. At 4 weeks, the cultured myoblasts were detached from the cell culture dish with $0.25 \%$ trypsinethylenediaminetetraacetic acid. After centrifugation at $300 \mathrm{~g}$ for 5 minutes, 70 million cells were resuspended in $2 \mathrm{~mL}$ of culture medium and used for each transplantation (Figure 3, $A-C$ ).

\section{Cell Labeling}

Sterile 4',6-diamidino-2-phenylindole (DAPI) stock solution (Sigma, St Louis, Mo) was added to the culture medium at a final concentration of $50 \mu \mathrm{g} / \mathrm{mL}$ on the day of implantation. The dye was allowed to remain in the culture dishes for at least 30 minutes. The cells were rinsed at least 6 times in Hanks balanced salt solution to remove all excess (unbound) DAPI. Myoblast cells were then collected (approximately $70 \times 10^{6}$ cells for 1 implantation) and resuspended in minimal volume of the serum-free Dulbecco's medium and stored on ice (less than 1 hour) until implantation into the myocardium.

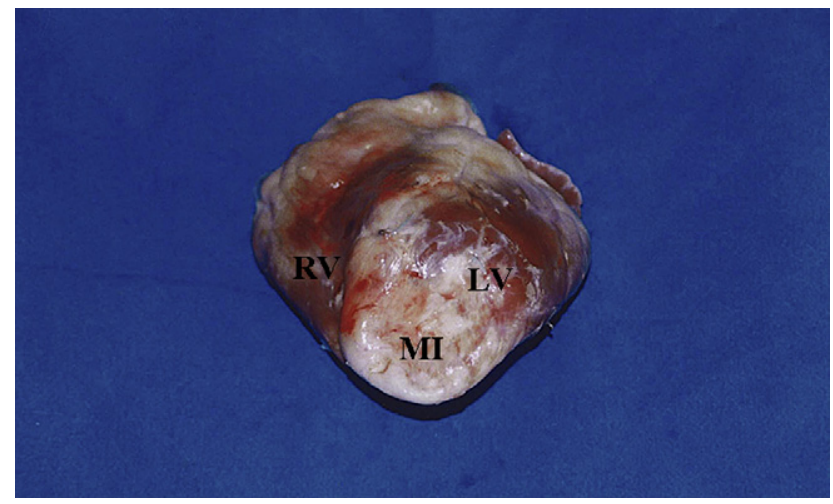

FIGURE 2. Explanted heart at 12 weeks of myocardial infarction, created by the ligation of the distal homonymous (equivalent to human left anterior descending) and second diagonal coronary arteries. View from the apex of the right ventricle $(R V)$, the left ventricle $(L V)$, and the myocardial infarction (MI). 


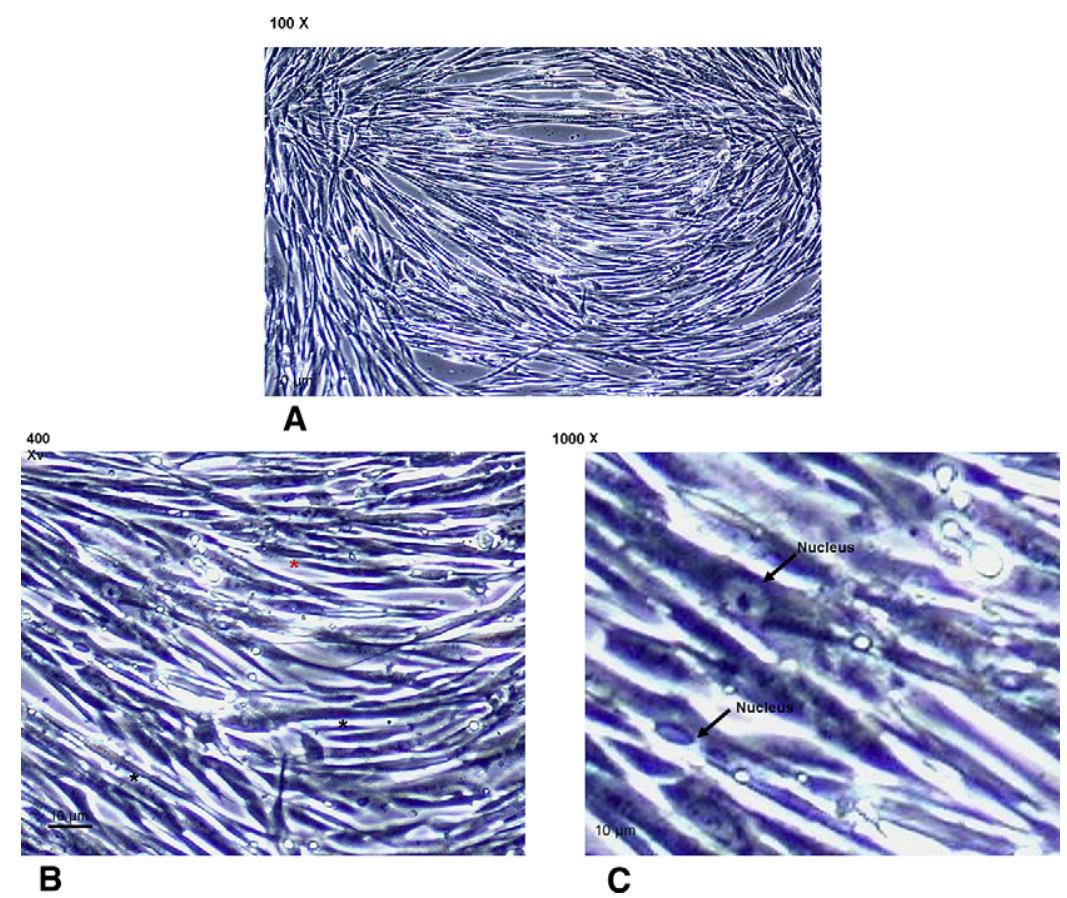

FIGURE 3. A, Skeletal myoblasts after 4 weeks of in vitro culture (phase contrast, magnification $\times 100)$. B, The red asterisk shows cells that appear with a typical myoblast phenotype. The black asterisks show cells proliferating toward a myotube-like shape (magnification $\times 400$ ). C, The arrows show nuclei with different morphology, from central round to peripheral elongated corresponding to different stages of skeletal muscle differentiation (magnification $\times 1000)$.

\section{Cell Implantation}

After a 4-week in vitro cell expansion period, the animals were operated on. After usual preparation and median sternotomy, the infarct area was identified and the cell suspension was injected by using an insulin syringe and a retrobulbar ophthalmic needle $(25$ gauge $\times 40 \mathrm{~mm})$. By 4 injection points, $70 \%$ of cells were implanted in the peri-infarct area (border zone), as residual irrigation and collateral myocardial revascularization in this intermediate area allows for a better survival of the implanted cells. The remaining $30 \%$ of cells were implanted in the central portion of the scar. The treated area was identified with 2 single sutures associated with metal ligating clips. The use of a long needle for cell implantation avoids multiple traumatic injection points. Cells were delivered when the implanted needle was progressively removed from the myocardium. To avoid regurgitation of the cell solution (channel leakage), we performed finger compression ( 1 to 2 minutes) at the needle injection sites after every injection.

\section{Pacemaker Implantation}

Animals were implanted with a pulse generator, Transform device (Model 4710, Medtronic, Minneapolis, Minn), which is an implantable programmable dual-channel pacemaker with the 2 channels coordinated by a synchronization circuit. The first channel is capable of sensing atrial signals and delivering stimuli to them when the sensed atrial intrinsic rate drops below the programmed pacing rate. The second channel is capable of generating a stimulation pulse synchronized to the first channel. The synchronization circuit determines the synchronization of the ventricles to paced or sensed atrial events.

Four epicardial electrodes (Medtronic SP 5591) were used for every sheep: 2 were implanted in the right atrium, 1 in the right ventricle, and 1 in the left ventricle near the infarcted area.

Stimulation protocol was done by sensing of the right atrium and biventricular pacing using an atrioventricular delay of $70 \mathrm{~ms}$ (the normal delay at rest in sheep is $110 \mathrm{~ms}$ ). This approach was used to induce the capture of ventricular activity. Atrial synchronized biventricular pacing was performed using the epicardial ventricular electrodes, with single pulses (amplitude of $5 \mathrm{~V}$ and a pulse width of 0.5 milliseconds).

\section{Evaluation of Ventricular Function}

Echocardiography (Sonos 1000, Hewlett-Packard, Palo Alto, Calif) with the aid of a 7-MHz transducer in the epicardial position was performed at cell implantation or at control medium injection or pacemaker implantation. Echocardiography was performed before infarction (preischemic), 4 weeks after infarction, and at 12 weeks after infarction. The global cardiac function was measured at the same time points in the 2-dimensional mode. Parameters included the LV end-diastolic and end-systolic diameters, the shortening fraction, the end-diastolic and systolic volumes, and the ejection fraction. The ejection fraction and shortening were calculated by the Teicholz method and were based on the LV end-systolic and end-diastolic diameters.

\section{Histology and Immunohistochemistry}

All sheep were killed 12 weeks after creation of infarct. The site of myocardial injury was identified and dissected. Five specimens were harvested, and each of these was cut into 2 pieces. The first piece was fixed in $10 \%$ formol, embedded in paraffin, and sectioned to yield $10-\mu \mathrm{m}$-thick slices. The sections were stained with hematoxylin and eosin. The second piece of each specimen was frozen in liquid nitrogen-cooled isopentane. Frozen biopsy tissue was stored at $-80^{\circ} \mathrm{C}$ until it was processed on a cryostat.

When cells were observed in the infarct sections, they were tested with fast and slow myosin heavy chain antibodies (Sigma Aldrich, St Louis, $\mathrm{Mo}$ ), which are specific for the skeletal isoform of adult fast and slow myosin.

For immunohistochemical studies, 5- $\mu$ m-thick sections of frozen tissues were fixed for 10 minutes in cold acetone, and endogenous avidin and biotin sites were blocked (Dako, Glostrup, Denmark). Samples were incubated with the myosin heavy chain antibodies $(1: 300)$ in $0.1 \%$ fetal calf serum 
for 1 hour, followed by incubation with biotinyl anti-mouse immunoglobulin (1:200) (Vector Laboratories, Burlingame, Calif), and finally were incubated with streptavidin-cyanine 2 (Amersham Biosciences, Buckinghamshire, UK) 1:800 in phosphate-buffered saline for 30 minutes. The slides were then mounted with the Immuno-mount system (Thermo Shandon, Runcorn, UK) and studied with an inverted fluorescent microscope (Nikon Eclipse TE300; Nikon Inc, Melville, NY).

\section{Statistical Methods}

Results are reported as percentage or mean \pm standard deviation. A paired or unpaired Student $t$ test was used to compare the groups when needed. A 1-way analysis of variance was used when more than 2 groups were present. When indicated, a Student-Newman-Keuls multiple comparison test was used as a post hoc test.

\section{RESULTS}

\section{Myocardial Infarction Creation}

Of 22 operated animals, 2 died during the creation of the infarction; both developed refractory ventricular fibrillation. Cardiac troponin I was chosen as an indicator of myocardial infarction. Cardiac troponin I values were expressed as mean \pm standard deviation. The average serum level of cardiac troponin I 1 day after infarction was $125.4 \pm 70 \mathrm{ng} / \mathrm{mL}$. No mortality was registered during reoperations or followup; at 12 weeks, there were 20 surviving animals (5 in each group).

\section{Cell Cultures}

Cell culture conditions were evaluated before cell implantation; the primary skeletal muscle cell culture contained about $90 \%$ myoblasts as determined with desmin immunofluorescence. All cultures showed 99\% viability before implantation by means of trypan blue exclusion assay. In addition, all cell culture media taken from the cultures before implantation tested negative for aerobic and nonaerobic bacterial contaminations.

\section{Echocardiography}

LV function and dimensions were quantified 4 (baseline) and 12 weeks after myocardial injury. At baseline, the mean ejection fraction and left ventricular end-diastolic volume (LVEDV) were similar in all 4 treatment groups (Table 1).

Over the course of 4 weeks, each group dilated their LV end-diastolic dimension compared with their preoperative value. At 12 weeks, a statistically significant attenuation of LV dilation was demonstrated with CRT + cells compared with cells-only group or CRT-only group $(P<.01$ for both comparisons). In those animals, LVEDV increased from $58.4 \pm 4.3$ to $64.6 \pm 6.6 \mathrm{~mL}$ (Figure $4, A$ ).

At 12 weeks, ejection fraction was significantly greater in the hearts treated with CRT + cells compared with those receiving only cells or only CRT $(P<.01$ for both comparisons). In those animals, ejection fraction was increased from $38.8 \% \pm 1.97 \%$ to $44.8 \% \pm 5.97 \%$ (Figure $4, B$ ).

Wall thickening was determined by echocardiography in the thinnest region of the infarct area 4 and 12 weeks after myocardial injury. At baseline, anterior wall thickness at diastolic phase did not differ among groups. Transplantation of cells and CRT caused an increase in diastolic wall thickening in the infarcted zone relative to cells-only and CRT-only groups $(P<.01$ for all; Figure $4, C)$.

\section{Identification of Implanted Cells}

Macroscopically, at 12 weeks, a local area of necrosis was consistently observed in the apex and anterolateral LV wall of all animals (Figure 2). Histological analysis with hematoxylin and eosin stain showed infarcted areas characterized by the replacement of healthy myocardium by adipose and fibrous tissue. The myocardial scars in sheep are predominantly infiltrated by adipose tissue.

By immunohistochemical analysis, sections from sheep treated with cells were positively stained with myosin heavy chain (the skeletal isoform of adult fast myosin heavy chain), and satellite cells were detected (Figure 5, $A$ ). This antibody did not react with healthy or ischemic cardiac sections. In 4 sheep of group 4 (pacing + cell), elongated skeletal muscle cells structures were observed that resembled multinucleated well-differentiated myotubes (Figure 5, B), and slow twitch type I fibers were identified across the sections. No skeletal muscle cells were found in the healthy myocardium. By fluorescence microscopy, satellite cells and myotubes were detected with their nucleus marked with DAPI stain, with better organization and greater number when comparing group 2 (cells) versus group 4 (pacing + cells) (Figures 6 and 7).

\section{DISCUSSION}

The prevalence of severe heart failure and the clear clinical limitations of conventional interventions have encouraged the development of new therapeutic tools. ${ }^{14,15}$ The

TABLE 1. Echocardiographic studies

\begin{tabular}{|c|c|c|c|c|c|c|c|c|c|}
\hline \multirow[b]{2}{*}{ Groups } & \multicolumn{3}{|c|}{ LVEDV (mL) } & \multicolumn{3}{|c|}{ LVAWd (mm) } & \multicolumn{3}{|c|}{ EF $(\%)$} \\
\hline & Preischemic & $4 \mathrm{wk}$ & $12 \mathrm{wk}$ & Preischemic & 4 wk & $12 \mathrm{wk}$ & Preischemic & $4 \mathrm{wk}$ & $12 \mathrm{wk}$ \\
\hline Control & $50 \pm 2.9$ & $59.5 \pm 6.3$ & $82 \pm 7.6$ & $6.7 \pm 0.8$ & $5.32 \pm 0.9$ & $3.1 \pm 2.0$ & $68.3 \pm 2.2$ & $39 \pm 1.8$ & $34.8 \pm 3.5$ \\
\hline Cells & $49 \pm 3.1$ & $56.4 \pm 4.6$ & $74.6 \pm 7.1$ & $6.5 \pm 1.1$ & $5.82 \pm 1.1$ & $3.9 \pm 1.8$ & $67.4 \pm 1.5$ & $39.7 \pm 2$ & $42.3 \pm 4.3$ \\
\hline CRT & $51 \pm 2.3$ & $57.1 \pm 3.6$ & $72.5 \pm 3.9$ & $7.1 \pm 0.9$ & $5.74 \pm 1.2$ & $3.3 \pm 1.7$ & $70.1 \pm 1.3$ & $38.8 \pm 1.7$ & $41.8 \pm 4.7$ \\
\hline CRT + cells & $48 \pm 3.0$ & $58.4 \pm 4.3$ & $64.6 \pm 6.6$ & $6.8 \pm 0.7$ & $5.6 \pm 1.1$ & $5.4 \pm 1.9$ & $68 \pm 1.9$ & $38.8 \pm 1.97$ & $44.8 \pm 5.97$ \\
\hline
\end{tabular}

Data are means \pm standard deviation. $L V E D V$, Left ventricular end-diastolic volume; $L V A W d$, anterior wall thickness at diastolic phase; $E F$, ejection fraction; $C R T$, cardiac resynchronization therapy. 

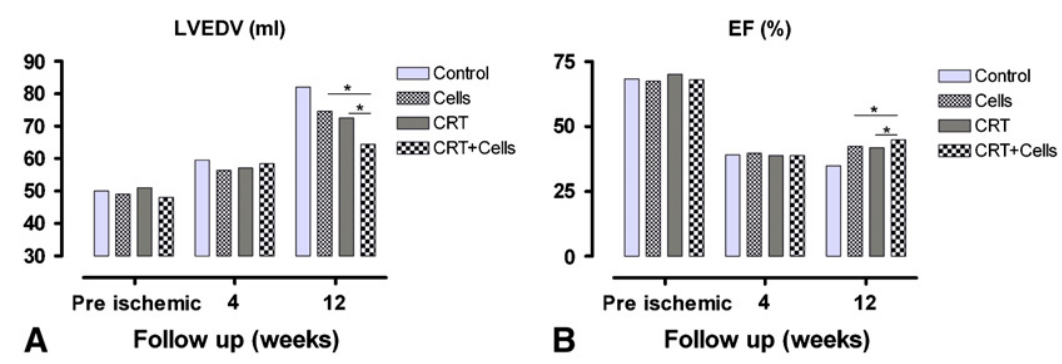

LVAWd (mm)

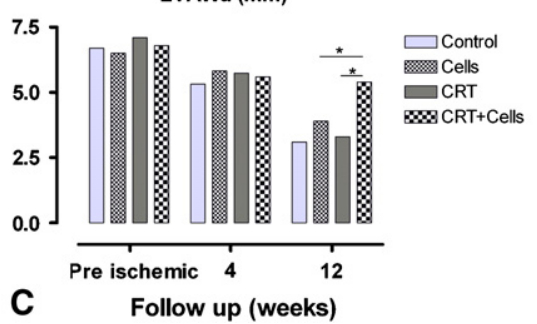

FIGURE 4. A, Echocardiographic studies. Left ventricular end-diastolic volume ( $L V E D V)$ evolution during follow-up $(* P<.01)$. B, Ejection fraction $(E F)$ evolution during follow-up $(* P<.01)$. C, Left ventricular anterior wall thickness at diastolic phase evolution during follow-up $(* P<.01) . C R T$, Cardiac resynchronization therapy; $L V A W d$, anterior wall thickness at diastolic phase.

natural evolution of heart failure with systolic function impairment leads to progression of the size of cardiac cavities. The interaction of hemodynamic processes influences this dilatation (Frank-Starling law). In cases of highly significant increases of LV volumes, actin-myosin cross-bridges stretch outside their physiologic limits, thus causing a decrease - instead of an increase - of contractile strength as well as structural changes due to the increase of end-diastolic pressures, which accompanies dilatation. In addition, this pathologic process involves extracardiac mechanisms, like metabolic changes at the systemic level. Thus, myocardial infarction leaves an akinetic fibrotic scar, which with adverse chamber remodeling leads to ventricular dilation and an overall loss of systolic and diastolic mechanical functions. Progressive LV remodeling after myocardial infarction has been viewed as an important contributor to progressive heart failure; an increase in regional remodeling strain led to an increase in myocar- dial apoptosis and regional contractile dysfunction in heart failure. $^{13}$

Cellular therapy for myocardial regeneration in ischemic and nonischemic cardiomyopathies is a rapidly burgeoning field, as evidenced by the number of randomized controlled trials of this treatment modality currently in progress or being initiated. The idea of transplanting single cells has a number of attractive attributes and depends on an everexpanding understanding of the molecular basis of angiogenesis and myogenesis. Cellular therapy's primary objective is to ensure the recolonization and restoration of postinfarction myocardial tissue, thus improving viability and function. The initial clinical trials of cell transplantation after a myocardial infarction have reported only limited improvements in ventricular function. Ongoing studies showed survival of the implanted cells, but no study showed active participation of the implanted cells in the force generation. This may due to lack of electrophysiologic connections

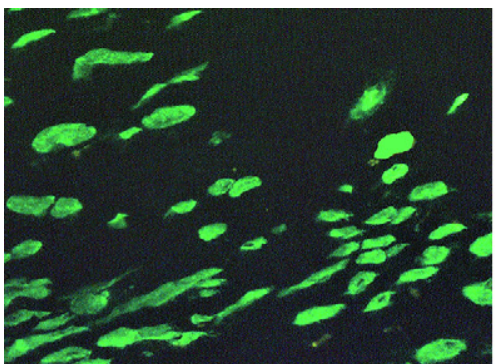

A

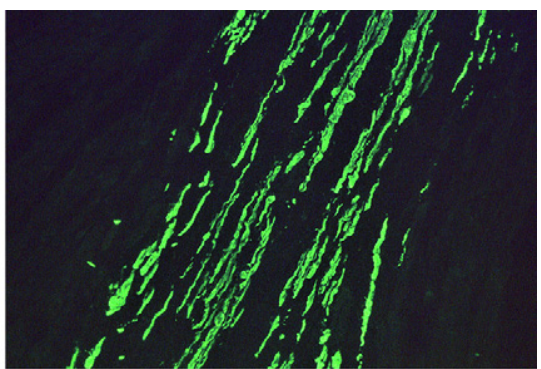

B

FIGURE 5. A, Histoimmunologic studies at 12 weeks in cell-treated group, showing isolated grafted myoblasts into the infarcted area. Stain with MY-32 antibody to skeletal myosin (original magnification, $\times 250$ ). B, Histoimmunologic studies at 12 weeks in the cell+electrostimulation group, showing a mixture of multinucleated myotubes and fibrillar configuration. Stain with MY-32 antibody to skeletal myosin (original magnification, $\times 200$ ). 


\section{ELECTROSTIMULATED CELLULAR CMP}

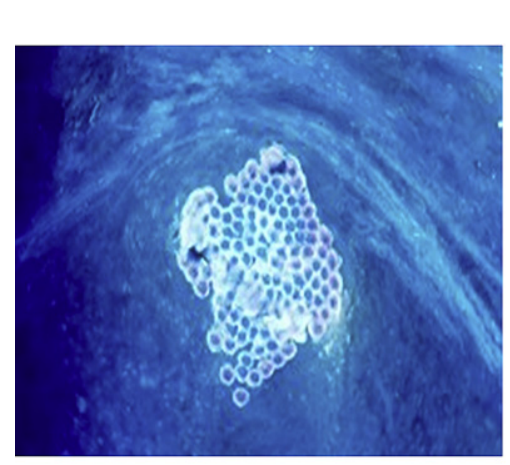

MULTINUCLEATED MYOTUBES
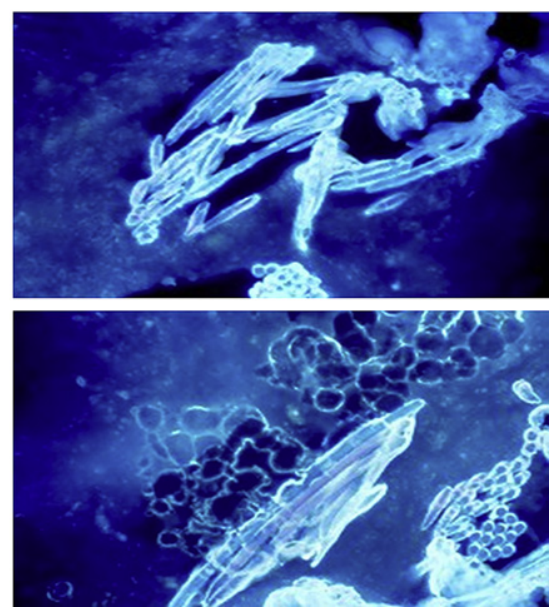

FIGURE 6. Cross and longitudinal section of multinucleated myotubes (marked with 4',6-diamidino-2-phenylindole dye) developed in the myocardial infarcted area after treatment with skeletal myoblasts associated with chronic electrostimulation (original magnification, $\times 360$ ).

between the implanted cells and the host myocardium and the lack of the gap junction protein (connexin 43). ${ }^{6,16-18}$

The concept of electrostimulation of homed myogenic cells (eg, skeletal myoblasts) is to transform the passive cells into active contracting cells, that is, from static cells to dynamic cells. It is important to remark that the physiologic myocardial cell potential is $85 \mathrm{mV}$. In our research protocol, we have been delivering a $5-\mathrm{V}$ pulse from a pacemaker, with the aim to create a potential difference greater than $85 \mathrm{mV}$ across each cell membrane. Therefore, we think that ventricular wall electrostimulation using $5-\mathrm{V}$ pulses should induce depolarization and contraction of the implanted stem cells. In our experimental model, ventricular walls were electrostimulated, and therefore the transplanted skeletal myoblasts and the infarcted myocardium were simultaneously activated. Importantly, during the postoperative evolution we did not observe any animal mortality, indicating that this approach may exclude the induction of malignant cardiac arrhythmias related with the association of cells and electrostimulation.

The principle of electrophysiologic conditioning of muscle fibers, developed by our group for the latissimus dorsi dynamic cardiomyoplasty procedure, was applied to this experimental study. ${ }^{11}$ But in the present approach, cells were stimulated with single pulses, not with pulse trains (bursts containing 6 spikes) as used in cardiomyoplasty. This was decided to avoid the risk of deleterious effects on myoblasts. ${ }^{19}$ A functional engraftment is required to augment synchronized contractility and to avoid potentially life-threatening alterations in the electrical conduction of the heart. Current evidence suggests that skeletal myoblasts or bone marrow-derived adult stem cells fail to electromechanically integrate into the recipient heart with direct

\section{CELLULAR ORGANIZATION AFTER PACING}
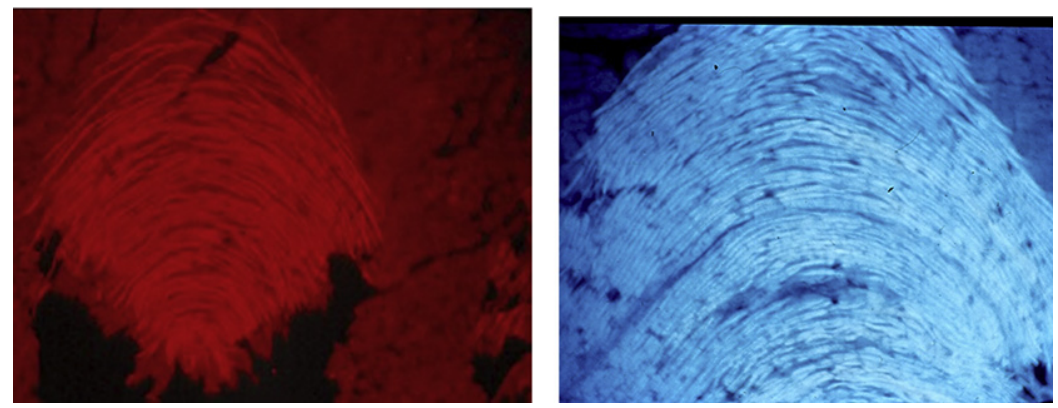

FIGURE 7. Left, Myoblasts organized and assembled in myofibers after pacing. Stain with antibody to slow-twitch skeletal myosin (original magnification, $\times 300$ ). Right, Fibrillar configuration of myoblasts marked with $4^{\prime}, 6$-diamidino-2-phenylindole dye in the infarcted area, group 4 (original magnification, $\times 320)$. 
consequences on their terminal differentiation. It has been suggested that the use of electrostimulation would drive stem cells toward differentiating into cardiac-type myogenic cells. This type of differentiation should include the induction of gap junction formation, improving stem cell engraftment and reducing the risk of arrhythmogenic events. ${ }^{3,20-22}$

A comparative study sinus node ("normal" electrical impulses) versus CRT (direct ventricular electrostimulation) has not been done. This treatment is designed for patients with heart failure. Most patients with heart failure present a mechanical and/or electrical ventricular dyssynchrony, resulting in increased ventricular wall stress and increased myocardial oxygen consumption. Both are detrimental to cell survival. These are minimized when CRT is activated and could contribute to better cell survival. ${ }^{8-10}$ The impact of submitting cell transplant to pulsed or static electrical fields is not very well known and is the subject of many studies. In a previous study, ${ }^{23}$ we analyzed this impact on cell cultures and found that in vitro electrostimulation of cell cultures was able to induce both morphologic and biochemical changes in human mesenchymal stem cells, realizing a shift toward a striated muscle cell phenotype expressing cardiac specific markers. Remarkably, the phenotype change could be achieved without any additional treatment or media supplementation or coculturing conditions defining what we could call a "clean" method to induce cell differentiation. Avoiding coculturing or growth factors use, issues concerning change in cell immunogenicity and biosafety following culturing conditions could be outwitted. Thus, our assumption is that the combination of coordinating the tissue contraction in addition to the application of pulse electrical field would be beneficial for the reasons exposed above. The results of the present study tend to support this hypothesis.

The effects of cell therapy on cardiac function need to be further investigated by analyzing the active contribution of transplanted cells to myocardial contractility, as until now the effects of this therapy seem principally limited to stabilization or reduction of ventricular dilatation (reverse remodeling) and improvement of myocardial viability. Cell transplantation for heart failure still raises several questions regarding cell delivery, cell survival, and cell injection site. The cell injection efficiency of epicardial, endocardial, and intracoronary cell delivery is still unknown. The low rate of cell survival and the effects when the injections are performed in the center of the infarct instead of the peri-infarct zones warrant additional research. ${ }^{1,5}$ The development of strategies for improving cell survival and differentiation (eg, by using prevascularization, preconditioning procedures like in vitro cell electrostimulation, cell cultures under hypoxia conditions, combination of angiogenic and myogenic stem cells, and tissue engineering approaches) seems to be of great interest. ${ }^{2,17,23-28}$

CRT is an effective therapy in symptomatic patients with drug-refractory heart failure with prolonged QRS and low ejection fraction. Long-term results of CRT on exercise tolerance and disease progression as evaluated by reversal of maladaptive remodeling process are rather limited, mostly reported in patients with sinus rhythm. However, it is estimated that less than half of patients with heart failure have dyssynchrony and as many as $30 \%$ of implanted patients are considered nonresponders. ${ }^{29-32}$

Despite progressive improvement of LV function and functional capacity induced by CRT, the long-term benefits can be limited in patients with large postischemic myocardial scars. In fact, it seems that the correction of conduction delays is not enough to improve heart failure symptoms when myocardial viability is severely compromised. ${ }^{10,32-34}$ For this reason, we underwent studies associating cell-based myocardial regeneration procedures with CRT. The goal was to associate cellular cardiomyoplasty with cardiac pacing to create a dynamic cellular cardiac support. Our hypothesis was that the combination of CRT with cell transplantation should be a superior treatment strategy in patients with heart failure. ${ }^{35}$ Electrostimulation of both ventricles following skeletal myoblast implantation seems to induce the contraction of the transplanted cells and a higher expression of slow myosin, which is better adapted for chronic ventricular assistance. Large randomized studies would be useful to further confirm our experimental results.

\section{Limitations of the Study}

The quantification of viable cells and the connections between the grafted cells and the scar area or native myocardium have not been specifically evaluated. Therefore, these particular points deserve future studies. Because in the present study animals were evaluated at 12 weeks, future investigations should include longer-term follow-up incorporating tissue Doppler imaging or another method to assess segmental contractility, scar size, and diastolic function of the treated ventricular wall.

We acknowledge Pierre Grandjean (Bakken Research Center, NL), Howard Leonhardt (Bioheart Inc, USA), Jorge Genovese (Pittsburgh University, USA), and Nermine Lila, Dana Budescu, Nathalie Goussef, Catherine Vaysettes, and Cyril Schneider-Maunoury (University of Paris, France).

\section{References}

1. McCue JD, Swingen C, Feldberg T, Caron G, Kolb A, Denucci C, et al. The real estate of myoblast cardiac transplantation: negative remodeling is associated with location. J Heart Lung Transplant. 2008;27:116-23.

2. Suuronen EJ, Price J, Veinot JP, Ascah K, Kapila V, Guo XW, et al. Comparative effects of mesenchymal progenitor cells, endothelial progenitor cells, or their combination on myocardial infarct regeneration and cardiac function. $J$ Thorac Cardiovasc Surg. 2007;134:1249-58.

3. Chachques JC, Salanson-Lajos C, Lajos P, Shafy A, Alshamry A, Carpentier A. Cellular cardiomyoplasty for myocardial regeneration. Asian Cardiovasc Thorac Ann. 2005;13:287-96.

4. Kan CD, Li SH, Weisel RD, Zhang S, Li RK. Recipient age determines the cardiac functional improvement achieved by skeletal myoblast transplantation. J Am Coll Cardiol. 2007;50:1086-92. 
5. Robey TE, Saiget MK, Reinecke H, Murry CE. Systems approaches to preventing transplanted cell death in cardiac repair. J Mol Cell Cardiol. 2008;45:567-81.

6. Jolicoeur EM, Granger CB, Fakunding JL, Mockrin SC, Grant SM, Ellis SG, et al. Bringing cardiovascular cell-based therapy to clinical application: perspectives based on a National Heart, Lung, and Blood Institute Cell Therapy Working Group meeting. Am Heart J. 2007;153:732-42.

7. Chachques JC, Acar C, Herreros J, Trainini JC, Prosper F, D'Attellis N, et al. Cellular cardiomyoplasty: clinical application. Ann Thorac Surg. 2004;77:1121-30.

8. Auricchio A, Prinzen FW. Update on the pathophysiological basics of cardiac resynchronization therapy. Europace. 2008;10:797-800.

9. Cazeau S, Alonso C, Jauvert G, Lazarus A, Ritter P. Cardiac resynchronization therapy. Europace. 2004;5(Suppl 1):S42-8.

10. Nagueh SF. Mechanical dyssynchrony in congestive heart failure: diagnostic and therapeutic implications. J Am Coll Cardiol. 2008;51:18-22.

11. Chachques JC, Abdel Shafy AB, Duarte F, Cattadori B, Goussef N, Shen L, Carpentier A. From dynamic to cellular cardiomyoplasty. J Card Surg. 2002; 17:194-200.

12. Monnet E, Chachques JC. Animal models of heart failure: what is new? Ann Thorac Surg. 2005;79:1445-53.

13. Yankey GK, Li T, Kilic A, Cheng G, Satpute A, Savai K, et al. Regional remodeling strain and its association with myocardial apoptosis after myocardial infarction in an ovine model. J Thorac Cardiovasc Surg. 2008;135:991-8, 998.e1-2.

14. Jessup M, Brozena SC. Guidelines for the management of heart failure: differences in guideline perspectives. Cardiol Clin. 2007;25:497-506.

15. Cleland JG, Coletta AP, Abdellah AT, Cullington D, Clark AL, Rigby AS. Clinical trials update from the American Heart Association 2007: CORONA, RethinQ, MASCOT, AF-CHF, HART, MASTER, POISE and stem cell therapy. Eur $J$ Heart Fail. 2008; 10:102-8.

16. Rajnoch C, Chachques JC, Berrebi A, Bruneval P, Benoit MO, Carpentier A. Cellular therapy reverses myocardial dysfunction. J Thorac Cardiovasc Surg. 2001; 121:871-8.

17. Chachques JC, Duarte F, Cattadori B, Shafy A, Lila N, Chatellier G, et al. Angiogenic growth factors and/or cellular therapy for myocardial regeneration: a comparative study. J. Thorac Cardiovasc Surg. 2004;128:245-53.

18. Carvalho KA, Simeoni RB, Guarita-Souza LC, Francisco JC, Abdelwahid E, Myiague NI, et al. Angiogenesis without functional outcome after mononuclear stem cell transplant in a doxorubicin-induced dilated myocardiopathy murine model. Int J Artif Organs. 2008;31:431-8.

19. Chachques JC. Cardiomyoplasty: is it still a viable option in patients with endstage heart failure? Eur J Cardiothorac Surg. 2009;35:201-3.

20. Iijima Y, Nagai T, Mizukami M, Matsuura K, Ogura T, Wada H, et al. Beating is necessary for transdifferentiation of skeletal muscle-derived cells into cardiomyocytes. FASEB J. 2003;17:1361-3.

21. Mills WR, Mal N, Kiedrowski MJ, Unger R, Forudi F, Popovic ZB, et al. Stem cell therapy enhances electrical viability in myocardial infarction. J Mol Cell Cardiol. 2007;42:304-14.
22. Carraro U. Long-term aneurally regenerated skeletal myofibers into heart: how long they could survive and grow by phasic daily FES? Basic Appl Myol. 2003; 13:53-63.

23. Genovese JA, Spadaccio C, Chachques E, Schussler O, Carpentier A, Chachques JC, Patel AN. Cardiac pre-differentiation of human mesenchymal stem cells by electrostimulation. Fron Biosci. 2009;14:2996-3002.

24. Hu X, Yu SP, Fraser JL, Lu Z, Ogle ME, Wang JA, Wei L. Transplantation of hypoxia-preconditioned mesenchymal stem cells improves infarcted heart function via enhanced survival of implanted cells and angiogenesis. J Thorac Cardiovasc Surg. 2008;135:799-808.

25. Memon IA, Sawa Y, Miyagawa S, Taketani S, Matsuda H. Combined autologous cellular cardiomyoplasty with skeletal myoblasts and bone marrow cells in canine hearts for ischemic cardiomyopathy. J Thorac Cardiovasc Surg. 2005;130:646-53.

26. Cortes-Morichetti M, Frati G, Schussler O, Van Huyen JP, Lauret E, et al. Association between a cell-seeded collagen matrix and cellular cardiomyoplasty for myocardial support and regeneration. Tissue Eng. 2007;13:2681-7.

27. Chachques JC, Trainini JC, Lago N, Cortes-Morichetti M, Schussler O Carpentier A. Myocardial Assistance by Grafting a New Bioartificial Upgraded Myocardium (MAGNUM trial): clinical feasibility study. Ann Thorac Surg. 2008;85:901-8.

28. Schussler O, Coirault C, Louis-Tisserand M, Al Chare W, Oliviero P, Menard C, et al. Use of arginine-glycine-aspartic acid adhesion peptides coupled with a new collagen scaffold to engineer a myocardium-like tissue graft. Nat Clin Pract Cardiovasc Med. 2009;6:240-9.

29. Conti JB, Sears SF. Cardiac resynchronization therapy: can we make our heart failure patients smarter? Trans Am Clin Climatol Assoc. 2007;118:153-64.

30. Young JB, Abraham WT, Smith AL, Leon AR, Lieberman R, Wilkoff B, et al. Combined cardiac resynchronization and implantable cardioversion defibrillation in advanced chronic heart failure: the MIRACLE ICD Trial. JAMA. 2003;289: 2685-94.

31. Doll N, Piorkowski C, Czesla M, Kallenbach M, Rastan AJ, Arya A, Mohr FW Epicardial versus transvenous left ventricular lead placement in patients receiving cardiac resynchronization therapy: results from a randomized prospective study. Thorac Cardiovasc Surg. 2008;56:256-61.

32. Rademakers LM, de Boeck BW, Maessen JG, Prinzen FW. Development of strategies for guiding cardiac resynchronization therapy. Heart Fail Clin. 2008;4: 333-45.

33. Fauchier L, Poret P, Robin I, de Labriolle A, Giraudeau C, Cosnay P, Babuty D Different criteria of cardiac resynchronization therapy and their prognostic value for worsening heart failure or major arrhythmic events in patients with idiopathic dilated cardiomyopathy. Am J Cardiol. 2006;97:393-9.

34. de Sisti A, Toussaint JF, Lavergne T, Ollitrault J, Abergel E, Paziaud O, et al. Determinants of mortality in patients undergoing cardiac resynchronization therapy: baseline clinical, echocardiographic, and angioscintigraphic evaluation prior to resynchronization. Pacing Clin Electrophysiol. 2005;28:1260-70.

35. Atoui R, Shum-Tim D, Chiu RC. Myocardial regenerative therapy: immunologic basis for the potential "universal donor cells." Ann Thorac Surg. 2008;86:327-34. 